\title{
COVID-19: MENGUJI KEBENARAN KONSPIRASI GLOBAL
}

\author{
Mukran H. Usman ${ }^{\mathrm{a}, 1,{ }^{*}}$, Azwar Iskandar ${ }^{\mathrm{b}, 2}$, Aswar $^{\mathrm{c}, 3}$ \\ ${ }^{a}$ STIBA Makassar, Jl. Inspeksi PAM, Makassar, 90111, Indonesia \\ ${ }^{b}$ STIBA Makassar, Jl. Inspeksi PAM, Makassar, 90111, Indonesia \\ c STKIP Muhammadiyah Barru, Jl. KH. Ahmad Dahlan, Barru, 90761, Indonesia \\ ${ }^{1}$ mukran@stiba.ac.id*;2azwar.iskandar@gmail.com; ${ }^{3}$ aswar@stkipmb.ac.id;
}

ARTICLE INFO

\section{ABSTRACT}

Article history:

Received : 2020-09-12

Revised : 2020-10-29

Accepted : 2020-12-21

Keywords:

Plague

Covid-19 Pandemic

Conspiracy

Strategy

Islam

Kata kunci:

Wabah

Pandemi Covid-19

Konspirasi

Strategi

Islam
The research attempted to explain the truth of the assumptions and accusations of some Muslims against the Covid-19 pandemic as a global conspiracy and to refute weak views and arguments related to it. This research applied descriptive qualitative methods using sociological, historical and heuristic approaches. The results showed that the existence of the Covid-19 pandemic as a disease was real, and not a conspiracy issue. The perceptions, arguments and understanding of some Muslims stating that the Covid-19 pandemic was a conspiracy had the potential effect to cause damage the life order as a state and society. In addition, if this understanding was not directed according to the correct Islamic guidance, it was worried that it would have a negative impact on the brotherhood and unity of Muslims. Some baseless assumptions and arguments regarding this epidemic can be answered, refuted and explained with strong and real arguments and evidence based on the hadiths of the Prophet Muhammad, valid narrations, and historical records of Muslims.

\begin{abstract}
ABSTRAK
Penelitian bertujuan untuk menjelaskan kebenaran anggapan dan tuduhan sebagian umat Islam terhadap wabah Covid-19 sebagai sebuah konspirasi global dan membantah berbagai pandangan dan argumen yang lemah terkait dengannya. Penelitian ini menggunakan metode kualitatif deskriptif dengan pendekatan sosiologis, historis dan heuristik. Hasil penelitian menunjukkan bahwa keberadaan wabah Covid-19 sebagai suatu penyakit adalah sesuatu yang nyata, dan bukan merupakan sebuah isu konspirasi. Persepsi, argumentasi dan pemahaman sebagian umat Islam yang menyatakan bahwa wabah Covid-19 adalah sebuah konspirasi berpotensi menimbulkan kerusakan dalam tatanan kehidupan bernegara dan bermasyarakat. Selain itu, apabila pemahaman ini tidak diarahkan sesuai tuntunan Islam yang benar, dikhawatirkan akan memberikan dampak buruk terhadap ukhuwah, persaudaraan dan persatuan umat Islam. Beberapa anggapan dan argumen yang tidak berdasar terkait wabah ini dapat dijawab, dibantah dan dijelaskan dengan dalil dan bukti yang kuat dan nyata berdasarkan hadis-hadis Rasulullah, riwayatriwayat yang sahih, dan catatan sejarah umat Islam.
\end{abstract}

\section{Pendahuluan}

Islam beserta ajarannya adalah cahaya kebenaran dan petunjuk bagi umat manusia yang tidak akan pernah sirna dari muka bumi
(Jazairi, 1994). Ajaran Islam akan menuntun manusia kepada kepemimpinan yang paripurna, menegakkan keadilan, membawa rahmat bagi segenap penduduk bumi, dan membawa manusia kepada kehidupan yang bahagia di dunia dan akhirat (Farid, 1999). 
Vol. 16, No. 2, Desember 2020, p. 122-131

Meskipun demikian, dalam sejarahnya, sampainya risalah Islam ke seluruh umat manusia bukanlah hal yang mudah, berbagai tantangan selalu hadir menyertainya, demikian pula para pengusung dakwah Islam (Ibrahim, t.t.).

Di antara masalah yang menjadi tantangan bagi umat Islam saat ini adalah problematika penyikapan sebagian umat Islam terhadap pandemi Covid-19. Tantangan yang mengemuka adalah adanya sebagian umat Islam yang memandang bahwa Covid-19 adalah sebuah "konspirasi" global yang ditujukan kepada umat Islam. Persepsi dan argumen mereka terkait hal ini pada dasarnya tidak didukung oleh dalil yang kuat. Di antara argumen tersebut adalah bawah pandemi ini bertujuan untuk menjauhkan umat Islam dari masjid, ingin merusak silaturahim (Mursid \& Firmansyah, 2020), dan berbagai argumentasi lainnya yang dipandang tidak pantas untuk disampaikan oleh sebagian umat Islam di tengah kondisi wabah Covid-19 (Fauzatul, 2020). Saat ini Covid-19 menjadi perhatian utama dunia. Cepatnya penyebaran penyakit disertai penambahan kasus yang masih terus melonjak, termasuk di Indonesia, serta beragamnya manifestasi klinis Covid-19 berpotensi pada jatuhnya sistem kesehatan masyarakat (Fitriani, 2020).

Beberapa lembaga dan institusi di Indonesia telah melakukan survei kepada masyarakat terkait hal ini. Misalnya, Pemerintah Kota Bogor melaporkan hasil survei bahwa ada $16 \%$ warga yang masih menyakini teori konspirasi virus corona dan $50 \%$ yang masih meragukan keberadaan virus ini, apakah hanya sebuah konspirasi atau nyata (Ratna Iskana, 2020). Pada wilayah lainnya, hasil survei Lembaga Riset dan Konsultan Spektrum Politika mengungkap 39,9\% warga Sumatera Barat meyakini pandemi Covid-19 merupakan konspirasi globa (Cahyana, 2020). Sementara itu, dalam sebuah studi studi yang diterbitkan American Journal of Tropical Medicine and Hygiene pada 10 Agustus 2020, para peneliti menemukan bahwa setidaknya ada 800 orang yang meninggal akibat informasi keliru saat pandemi corona. Peneliti menemukan 1.856 klaim yang salah (82\%), 204 informasi yang benar $(9 \%), 176$ info menyesatkan $(8 \%)$, dan 31 klaim yang tidak terbukti (1\%). Dari jumlah tersebut, mereka menemukan Indonesia sebagai salah satu negara paling 'infodemik' di dunia (Rahman Nugraha, 2020).

Berangkat dari hal tersebut, penting untuk menjelaskan fenomena ini dalam sudut pandang Islam dalam sebuah kajian ilmiah dalam rangka meluruskan pandangan, persepsi dan argumentasi yang berpotensi melemahkan barisan kaum muslimin terkait wabah Covid-19. Oleh karena itu, permasalahan yang mengemuka untuk dijawab adalah apakah benar bahwa Covid19 adalah sebuah konspirasi global untuk melemahkan umat Islam? Apakah pandangan atau argumen sebagian umat Islam yang menyatakan bahwa wabah Covid-19 sengaja direkayasa untuk menjauhkan umat Islam dari masjid, ingin merusak silaturahim, dan berbagai argumentasi lainnya adalah benar? Untuk menjawab permasalah tersebut, penelitian ini dilakukan dengan tujuan untuk menjelaskan kebenaran anggapan dan tuduhan sebagian umat Islam terhadap wabah Covid-19 sebagai sebuah konspirasi global dan membantah berbagai pandangan dan argumen yang lemah terkait dengannya. Penelitian ini diharapkan dapat menjadi sebuah bahasan ilmiah sebagai bentuk kontribusi dalam menjaga persatuan dan kesatuan umat Islam di tengah berbagai macam persepsi pro dan kontra tentang pandemi Covid-19.

\section{Tinjauan Pustaka}

Untuk menguatkan kajian penulis dalam artikel ini, terdapat beberapa kajian terdahulu yang digunakan sebagai bahan dasar pembahasan dan pustaka penelitian ini.

Pertama, pengkajian yang dilakukan oleh Mahmuddin dan Syandri (2020) dengan judul "Qadariyah, Jabariyah dan Ahlussunnah (Studi Komparatif Merespon Kebijakan Pemerintah dan Fatwa MUI Dalam Mencegah Penularan Covid-19)." Pengkajian ini menyimpulkan bahwa terdapat pemahaman dalam tubuh umat Islam yang bertentangan dengan pemahaman Islam yang benar, terutama dalam menyikapi wabah Covid-19, di antara pemahaman tersebut adalah penafian akan wajibnya melakukan ikhtiar (usaha menjauhkan diri dari wabah), 
sebagaimana yang dipahami oleh kelompok Jabariyah, demikian pula kelompok Qadariyah yang menafikan tawakkal dalam menyikapi suatu musibah (Syandri, 2020).

Kedua, pengkajian oleh Supriatna dengan judul "Wabah Corona Virus Disease Covid19 Dalam Pandangan Islam." Dalam kajiannya menyimpulkan bahwa wabah Covid-19 merupakan ujian dari Allah swt kepada manusia, dan ujian tersebut bukanlah pertama kali terjadi, namun ujian wabah juga pernah terjadi di zaman Rasulullah saw (Supriatna, 2020).

Ketiga, pengkajian oleh Usman, Aswar, dan Sam dengan judul "Covid-19 Dalam Perjalanan Akhir Zaman: Sebab, Dampak dan Anjuran Syariat Dalam Menghadapinya." Pengkajian ini menjelaskan bahwa wabah adalah merupakan salah satu tanda dari pada bencana akhir zaman yang telah dikabarkan dalam hadishadis Rasulullah saw, serta menjelaskan tentang anjuran syariat Islam untuk umat manusia dalam menghadapinya (Usman, Aswar, \& Sam, 2020).

Beberapa kajian atau penelitian terdahulu di atas belum mengkaji dan membahas terkait fenomena atau tuduhan "konspirasi" terhadap wabah Covid-19 sebagaimana yang telah disebutkan sebelumnya. Oleh karenanya, penelitian ini memiliki kebaharuan pembahasan karena berupaya untuk menjelaskan fenomena atau anggapan tersebut yang belum didapatkan pada penelitian-penelitian sebelumnya. Penelitian ini berupaya untuk memberikan wacana keilmuan dan pencerahan, terkhusus kepada mereka yang masih beranggapan bahwa wabah Covid-19 merupakan sebuah konspirasi, sehingga menafikan sejarah tentang wabah dan menafikan fatwa alim ulama yang memiliki otoritas keilmuan, wawasan dan pengetahuan akan realita yang ada.

\section{Metodologi Penelitian}

Dalam melakukan penelitian ini, penulis menggunakan metode kualitatif deskriptif dengan menggunakan pendekatan studi kasus eksplanatoris, pendekatan sosiologis dan pendekatan historis. Pendekatan studi kasus eksplanatoris merupakan suatu strategi penelitian untuk menyelidiki fenomena
Covid-19 dalam konteks kehidupan nyata. Pendekatan sosiologis yaitu metode untuk memahami karakter keilmuan masyarakat dalam penyikapan tentang wabah Covid-19. Pendekatan historis digunakan sebagai upaya untuk menganalisis peristiwa wabah yang pernah terjadi dalam sejarah negeri-negeri Islam.

\section{Hasil dan Diskusi}

\section{Wabah dalam Islam}

Secara bahasa, wabah adalah sebuah kata yang memiliki akar kata dari bahasa Arab yaitu al-Waba', dalam kitab Lisanul Arab bahwa wabah diartikan penyakit tho'un yaitu penyakit yang menyebar sangat luas. Secara istilah, wabah adalah tho'un, yaitu sejenis penyakit yang sama yang menimpa banyak orang di suatu daerah dengan jenis penyakit yang tidak seperti penyakit-penyakit lainnya (Al-Tujaibi, t.t.). Demikian pula dalam kitab al-Taudih li Syarhi al-Jami' al-Shohih oleh Ibnu Mulqin al-Syafi'i, beliau mengatakan bahwa wabah adalah penyakit tho'un yang merupakan satu jenis penyakit yang menyebar di suatu daerah, dan penyakit tersebut berbeda dengan penyakit-penyakit yang biasa menimpa manusia (Al-Syafi'i, 2008). Dengan demikian, wabah yang menjadi istilah penyakit menular dan mematikan hari ini adalah tha'un yang telah disebutkan dalam beberapa hadis Rasulullah saw.

Wabah merupakan istilah yang secara jelas disebutkan dalam hadis-hadis Nabi saw. Hadis-hadis ini tentu untuk menguatkan akan keberadaan wabah sebagai suatu penyakit yang dapat menimbulkan pandemi kepada dunia dan manusia. Beberapa hadis tersebut adalah sebagai berikut;

Pertama: Hadis Nabi saw yang datang dari riwayat sahabat yang mulia, Jabir ibn Abdillah ra.

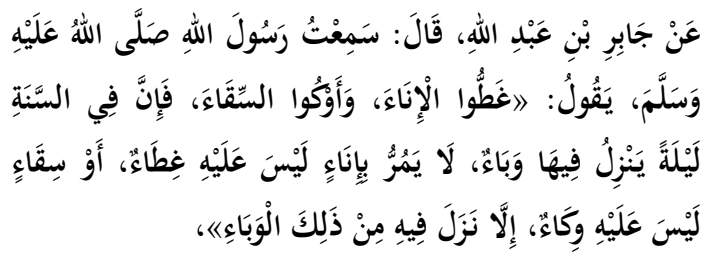

Artinya: Dari Jabir ibn Abdillah, beliau berkata, telah mendengar dari Rasulullah saw beliau bersabda: Tutuplah wadah air, ikat dan tutuplah tempat air, karena setiap 
Vol. 16, No. 2, Desember 2020, p. 122-131

malam dalam setahun, ada wabah yang turun, dan tidaklah wabah tersebut melewati wadah yang tidak tertutup dan tempat air yang tidak tertutup, kecuali wabah tersebut akan menimpa wadah dan tempat air (AlNaisaburi, t.t.-b).

Kedua: Hadis dari sahabat Ibnu Abbas ra. tentang larangan masuk ke tempat terjadinya wabah;

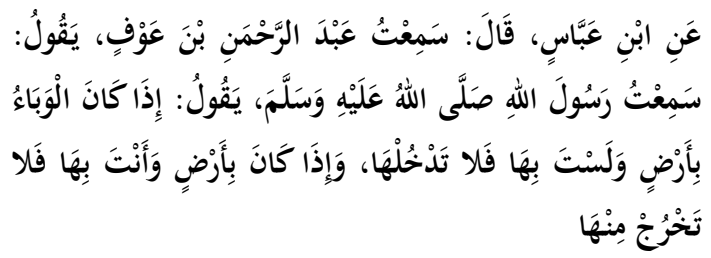

Artinya: Dari Ibnu Abbas beliau berkata, beliau mendengar Abdurrahman ibn Auf berkata; beliau mendengar Rasulullah saw. bersabda: Apabila kalian mendengar ada wabah di suatu tempat, maka janganlah masuk ke tempat tersebut, dan apa bila engkau berada di tempat wabah tersebut, maka janganlah keluar (Hambal, 2001).

Ketiga: Hadis dari Usamah ibn Zaid ra. tentang wabah adalah kotoran yang Allah swt jadikan sebagai ujian bagi mereka yang kufur kepada-Nya.

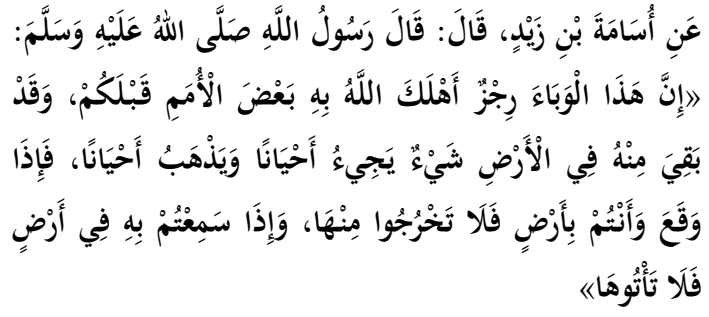

Artinya: Dari Usamah ibn Zaid berkata, adalah Rasulullah saw. bersabda: Sesungguhnya wabah ini adalah kotoran yang dengannya dahulu Allah telah membinasakan suatu kaum, dan wabah itu masih tersisa pada kaum setelahnya, yang bisa datang kembali dan bisa hilang, dan apa bila kalian berada di tempat tersebut, maka jangan keluar, dan apabila kalian mendengarnya berada di suatu tempat, maka janganlah masuk ke tempat tersebut (AlAzadi, t.t.).

Wabah dalam sejarah Islam seolah tidak tidak pernah berhenti dari sejak zaman Nabi saw yang terjadi di beberapa wilayah (AlMahasin, t.t.), kemudian terjadi pada zaman Umar ibn Khattab, dan zaman selanjutnya.
Bahkan dalam kitab al-Nujum al-Zahiroh fi Muluki Miser wa al-Qohiroh disebutkan terdapat 15 wabah yang terjadi di masa bani Umayyah. Berikut beberapa rentetan sejarah wabah dalam Islam.

Pertama: Wabah yang terjadi pada tahun 18 H/ 693 M, yang dikenal dengan Tho'un Amawas (Al-Damsiqi, t.t.). Wabah ini menimpa negeri Syam pada masa pemerintahan Umar ibn Khattab ra. Dengan jumlah yang meninggal sebanyak 25 ribu orang (Al-Atsir, 1997). Musibah wabah ini juga merenggut jiwa sahabat senior Rasulullah saw. Di antaranya adalah Abu Ubaidah ibn al-Jarrah yang merupakan gubernur Syam, Mu'az ibn Jabal, Yazid ibn Abi Sufyan, Syarhabil ibn Hasanah, dan AlHaris ibn Hisyam ibn al-Mugiroh (Khayyat, t.t.).

Kedua: Wabah yang terjadi di kota Basra (Irak) pada tahun 69 H/ 688 M, di masa pemerintahan Ibnu Zubair, yang dikenal dengan istilah Tho'un al-Jarif (AlDayanwari, 1992). Wabah ini terjadi selama 3 hari, setiap harinya, yang meninggal mencapai 70 ribu orang, termasuk 70 anakanak dari sahabat Anas ibn Malik juga meninggal (Al-Dzahabi, t.t.).

Ketiga: Wabah yang terjadi di wilayah Washit di kota Basrah Irak pada tahun $86 \mathrm{H} /$ 704 M, dan dikenal dengan nama Thoun alFatayat (Al-Dzahabi, 1993). Wabah ini pertama kali menyebar dari para gadis-gadis di kota Washit di Basrah pada bulan Syawal, akibat dari pada wabah ini, salah seorang putra mahkota bani Umayyah meninggal dunia, yaitu Abdul Malik ibn Umar ibn Abdul Aziz dan banyak dari para bangsawan (Al-Suyuti, 2004).

Keempat: Wabah yang terjadi di Tunisia, tepatnya di Kota al-Qairawan pada tahun 395 H (Al-Marakisyi, 1983). Disebutkan dalam kitab al-Bayan al-Mugribi fi Akbar alAndalus wa al-Magribi oleh Ibnu Azari alMarakisyi, beliau menceritakan tentang akibat wabah yang terjadi di Afrika ketika itu, dengan banyaknya korban yang meninggal dan keadaan yang sangat mengerikan di kota al-Qairawan. Beliau mengatakan; "Pada tahun 395 H di Afrika terjadi bencana besar yang menjadikan tiraitirai kehidupan tersingkap, banyak orang fakir meninggal, harta orang-orang kaya 
yang hilang, harga barang-barang melambung tinggi, dan sedikitnya makanan pokok. Penduduk pedesaan meninggalkan kampung halaman mereka sehingga banyak rumah-rumah yang kosong dan tidak tersisa orang yang mewarisinya. Kondisi parah ini disertai dengan wabah tho'un yang menyebabkan meninggalnya mayoritas orang-orang, baik orang kaya maupun orang miskin. Dalam kondisi tersebut, tidak akan mendapati orang yang beraktifitas kecuali untuk berobat, mengunjungi orang yang sakit, menyiapkan untuk mengurus orang yang meninggal, mengiringi jenazah, atau kembali dari menguburkan jenazah, dan, yang meninggal dalam bencana tersebut bermacam-macam golongan manusia dari ulama, pedagang, wanita, dan anak-anak yang jumlahnya tidak ada yang bisa menghitungnya kecuali Allah swt, bahkan, masjid-masjid di al-Qairawan pun kosong tanpa ada yang melaksanakan salat" (AlMarakisyi, 1983).

Kelima: Wabah yang dikenal dengan alTho'un al-Aswad yang terjadi mulai tahun 735-749 H (Al-Samiri, 2000). Wabah ini berawal dari Asia Tengah pada tahun $735 \mathrm{H}$, kemudian meluas ke dataran Eropah yang melewati Italia, Prancis, Skandinavia, dan kemudian tahun 748 masuk ke wilayah kekuasaan Islam Andalus, yaitu kota Barcelona, Valencia dan berakhir di kota Garnata tahun $749 \mathrm{H}$, dengan ribuan penduduknya yang meninggal dunia (AlSamiri, 2000).

Masih banyak peristiwa wabah yang terjadi dalam sejarah Islam, dengan dampak yang sangat besar, baik jiwa maupun materi. Namun, penulis menganggap bahwa kelima peristiwa wabah yang telah dipaparkan, sudah sangat memberikan gambaran akan keberadaan wabah yang nyata, dan bukanlah hanya sebuah kebohongan, apalagi bila mau dikatakan sebagai sebuah "konspirasi".

\section{Konspirasi dan Wabah}

Dalam kitab Takmilatu al-Ma'ajim alArabiyyah, "konspirasi" bermakna kesepakatan khusus dengan melakukan suatu kejahatan melawan pemerintah atau suatu negara (Duzi, 2008). Konspirasi dalam pengertian hukum kriminal adalah; suatu perencanaan antara dua orang atau lebih dengan tujuan pengambilan kekuatan pada suatu hukum kekuasaan atau melakukan perubahan pada suatu hukum sehingga terjadi ketidakamanan negara. Pengertian yang lain dari konspirasi adalah satu bentuk tipu daya dengan melakukan perbuatan permusuhan kepada satu hukum, atau negara, atau pribadi, yang perbuatannya telah direncanakan dengan secara sembunyi-sembunyi dan perbuatannya telah direncanakan dengan sebaik-baiknya.

Dari pengertian di atas tentang konspirasi, dapat disimpulkan bahwa konspirasi adalah sebuah perencanaan kejahatan yang dilakukan oleh manusia yang secara umum berkenaan dengan perebutan kekuasaan dari suatu pemerintah atau kelompok atau komunitas, dan atau perubahan pada suatu hukum.

Konspirasi kepada Islam dan atau umat Islam adalah perkara yang telah ada sejak zaman Rasulullah saw, di antaranya mulai dari konspirasi suku Qurais kepada Rasulullah (Khotib, t.t.), konspirasi Yahudi kepada beliau dan tidak luput konspirasi orang-orang munafik (Al-Nadawi, t.t.). Demikian pula banyak usaha dari orangorang kafir untuk memadamkan cahaya Islam, namun semuanya mengalami kegagalan, karena Allah swt senantiasa menjaga agama-Nya. Allah swt berfirman:

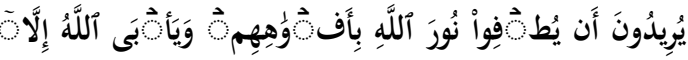

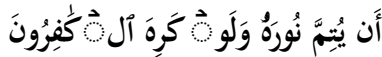

Artinya: "Mereka ingin memadamkan cahaya Islam dengan lisan-lisan mereka, namun Allah menolak, dan Allah tetap menyempurnakan cahaya-Nya sekalipun orang-orang kafir membencinya." (Q.S AtTaubah [9]:32)

Konspirasi kepada Islam adalah sesuatu yang nyata, dan sejarah telah mencatat dan mengabadikannya dalam kitab-kitab para ulama untuk menjadi pelajaran bagi generasi Islam yang selanjutnya. Berbagai bentuk konspirasi tersebut adalah konspirasi pada pengrusakan ajaran-ajaran pokok Islam, konspirasi untuk meruntuhkan kekuasaan Islam, dan konspirasi untuk memecah belah persatuan kaum muslimin. Di antara bentuk konspirasi kepada ajaran pokok Islam adalah dengan usaha mengaburkan pemahaman Islam dari dasarnya, dan nilai-nilai pokok ajaran Islam dengan cara merusak sejarah 
Vol. 16, No. 2, Desember 2020, p. 122-131

Islam dan menjauhkan umat Islam dari mempelajari bahasa Arab sebagai alat dalam memperdalam ajaran Islam (Al-Jundi, t.t.). Sedangkan konspirasi terhadap kekuasaan Islam, di antaranya terjadi pada Daulah Usmaniyyah yang pernah memimpin dunia selama hampir 700 tahun lamanya. Perjalanan kepemimpinan Islam di masa ini tidak luput dari buruknya konspirasi untuk meruntuhkan kepemimpinan tersebut. Seruan kepada al-Qaumiyyah al-Atrak menjadi satu senjata untuk mengusir bangsa Arab dari tanah Turki dengan terlebih dahulu melakukan perubahan pada undang-undang negara dan pada bahasa, kemudian membuat keributan politik, dan berakhir pada perebutan kekuasaan dari daulah Islamiyah menjadi negara sekuler, yang dimulai pada awal tahun keruntuhan daulah tersebut pada tahun $1492 \mathrm{M}$.

\section{Covid-19: Benarkah Sebuah Konspirasi?}

Benarkah ada konspirasi pada suatu peristiwa wabah yang banyak merenggut jiwa manusia pada suatu masa, seperti wabah Covid-19 yang menimpa dunia hari ini? atau apakah wabah tersebut benar-benar terjadi tanpa ada konspirasi jahat di dalamnya?

Keberadaan wabah yang menular telah disebutkan dalam hadis-hadis Rasulullah sebagaimana yang telah disebutkan. Dengan demikian, untuk mengatakan bahwa wabah Covid-19 adalah sebuah konspirasi merupakan anggapan yang tidak memiliki dasar yang kuat. Hadis Nabi menyebutkan dengan sangat jelas akan keberadaan wabah, bahkan dalam hadis Jabir ibn Abdillah, Nabi menyebutkan keberadaan wabah yang datang setiap tahun, dan lebih diperjelas lagi bahwa wabah itu datang dari tempat-tempat air yang ada di dalam rumah kita (Al-Naisaburi, t.t.a). Adanya sisi kesamaan antara wabah Covid-19 dan wabah yang pernah ada dalam sejarah umat Islam, demikian pula dengan bencana kematian yang ditimbulkannya, bencana materi, bencana sosial, serta jangkauan sebarannya, menjadi dasar kuat bagi penulis sehingga dapat menarik benang merah bahwa wabah ini bukanlah sebuah konspirasi.

Beberapa anggapan dan argumen yang tidak berdasar terkait wabah ini, dapat dijelaskan dan dibantah dengan uraian sebagai berikut.

Pertama, "jumlah kematian seolah-olah dibesar-besarkan". Sesungguhnya, jumlah kematian yang ditimbulkan dari wabah Covid-19 bila dibandingkan dengan wabah yang pernah ada dalam sejarah Islam sebenarnya masih lebih sedikit. Dalam catatan sejarah, sebagaimana disebutkan di dalam kitab al-Muntadzom fi Tarikh alMuluk wa al-Umam, kematian akibat dari wabah berlangsung selama 4 hari, hari pertama jumlah kematian 70 ribu, hari kedua jumlah kematian 71 ribu, hari ketiga 70 ribu, dan hari keempat kematian yang tidak terhitung, dan Cuma menyisakan beberapa orang dari penduduk daerah tersebut (AlJauzi, 1992). Demikian pula wabah Tha'un Amawas tahun $18 \mathrm{H}$, dengan jumlah kematian mencapai 25 ribu orang, dengan yang ikut meninggal dalam wabah ini adalah para sahabat-sahabat Rasulullah saw, seperti Abu Ubaidah ibn al-Jarrah, Mu'az ibn Jabal, Sarhabil ibn Hasanah, dan beberapa sahabat lainnya (Al-Damsiqi, t.t.).

Adapun apabila kematian akibat wabah Covid-19 ini adalah sebuah konspirasi bagi Islam dan umatnya, tentu saja yang menjadi korban hanyalah dari kalangan kaum muslimin saja, namun demikian realita yang ada bahwa kematian akibat wabah ini menimpa muslim dan kafir. Bahkan beberapa negara Eropa mencatat kematian akibat wabah Covid-19 cukup besar, mengalahkan jumlah kematian yang ada di negara-negara Islam, seperti Jerman dengan jumlah kematian 100 per satu juta, Kanada 180, dan 300 di Amerika Serikat, serta lebih dari 500 di Inggris, Italia dan Spanyol (Naufal Dzulfaroh, t.t.). Hal ini semakin menguatkan fakta bahwa wabah ini bukanlah sebuah konspirasi sebagaimana yang dipersangkakan sebagian orang, namun wabah ini benarbenar adalah sebuah peristiwa dan bencana sebagaimana yang telah disebutkan dalam hadis-hadis Rasululullah saw.

Kedua, "durasi atau lama penyebaran seolah-olah sengaja dipanjangkan, demikian pula aturan Pembatasan Sosial Berskala Besar (PSBB)". Apabila melihat wabah yang pernah ada, didapati bahwa ada wabah yang terjadi belasan tahun lamanya, seperti wabah Tha'un al-Aswad yang terjadi mulai tahun 
735 - 749 H (Al-Samiri, 2000), yang membawa kematian hampir $1 / 3$ penduduk bumi sebagaimana yang disebutkan dalam kitab Qissatu al-Hadarah (Dyurant, 1988). Demikian pula dengan wabah flu Spanyol yang kemudian menjadi pandemi global, dan membunuh 21 sampai 50 juta orang di seluruh dunia, termasuk Indonesia, dimana wabah ini berlangsung selama dua tahun, dari bulan Maret 1918 sampai September 1919 M (Lie, 2018). Begitu juga, peristiwa wabah yang terjadi selama beberapa tahun, di antaranya; pandemi wabah kolera tahun 1852-1860 M, yang berasal dari India, kemudian menyebar ke Amerika, Eropa dan Afrika, wabah flu Rusia 1889-1890 M, yang pertama kali muncul di Turkestan kemudian menyebar ke Eropa, wabah flu Asia 1956$1958 \mathrm{M}$, yang berasal dari Tiongkok dan menyebar ke Amerika (Anggita, 2020).

Adapun terkait dengan kebijakan atau aturan pembatasan sosial, Nabi sendiri telah membuat aturan pembatasan yang melebihi aturan pembatasan sosial yang ada sekarang, yaitu Nabi melarang untuk orang yang berada di dalam suatu wilayah yang terdampak wabah untuk tidak keluar dari tempat tersebut, sebagaimana Nabi melarang untuk orang yang berada di luar wilayah terdampak tersebut untuk tidak masuk (Hambal, 2001). Bahkan, sahabat yang mulia Amru ibn al-Ash dalam peristiwa wabah Amawas tahun $18 \mathrm{H}$, memerintahkan penduduk negeri Syam untuk keluar dari kota dan menuju ke gununggunung (Al-Damsiqi, 1997), dan ini menurut hemat penulis merupakan bentuk pembatasan sosial terbesar sepanjang sejarah dunia.

Ketiga, "wabah Covid-19 direkayasa untuk menjauhkan umat Islam dari masjid, sehingga dengan wabah ini, tidak ada lagi masjid yang terbuka bagi kaum muslimin untuk melaksanakan salat". Sebagai jawabannya adalah bahwa wabah yang pernah ada sebelumnya juga telah menyebabkan masjid-masjid ditutup dan dikosongkan dari jemaah salat, seperti yang pernah terjadi pada peristiwa wabah Andalus pada tahun $448 \mathrm{H}$, sebagaimana yang diceritakan oleh Imam al-Dzahabi dalam kitab Siyar A'lam al-Nubala', beliau mengatakan,

"terjadi pada tahun tersebut kemarau dan wabah yang panjang di Mesir dan Andalus, dan belum pernah terjadi sebelumnya musibah kemarau dan wabah yang besar di Kota Qurtuba, yang menyebabkan masjidmasjid ditutup, dan tahun wabah tersebut juga dinamakan sebagai tahun kelaparan." (Al-Dzahabi, 2006).

Demikian pula apa yang disebutkan oleh Ibnu Azari al-Marakisyi dalam kitab alBayan al-Magribi fi Akbar al-Andalus wa alMagrib, beliau menyebutkan peristiwa wabah pada tahun $395 \mathrm{H}$ di wilayah Afrika yang menyebabkan penutupan masjid-masjid akibat wabah. Beliau mengatakan,

"meninggal (dalam wabah) semua lapisan masyarakat ketika itu, baik itu para penuntut ilmu, pedagang, wanita, anak-anak, yang jumlah kematian tidak bisa diketahui kecuali Allah swt yang mengetahuinya, dan masjidmasjid di kota Qairawan kosong dari jemaah." (Al-Marakisyi, 1983).

Adapun alasan penutupan masjid-masjid untuk sementara waktu, merupakan satu bentuk pencegahan terjadinya penularan wabah yang lebih luas. Penutupan tersebut merupakan hasil dari kesepakatan para ulama dan pemerintah. Dibantara fatwa ulama yang menjadi pengangan banyak umat Islam tentang bolehnya menutup masjid untuk sementara waktu karena satu kebutuhan yang darurat, yaitu fatwa Syekh al-Utsaimin rahimahullah bahwa menutup masjid-masjid dan kakbah dan yang lain-lain boleh dilakukan selama hal tersebut adalah untuk suatu kebutuhan, dan tidak boleh dikatakan bahwa ini adalah bentuk pelarangan dari di memakmurkan masjid.

Keempat, "wabah Covid-19 ditujukan untuk merusak silaturahim". Perlu dipahami, Nabi saw telah memberikan sebuah konsep hidup sehat ketika terjadi wabah. Di antaranya adalah Nabi melarang salah seorang sahabat yang sedang menderita sakit untuk memberikan baitnya langsung kepada Rasulullah, sebagaimana dalam sebuah riwayat yang terdapat dalam Shahih Muslim:

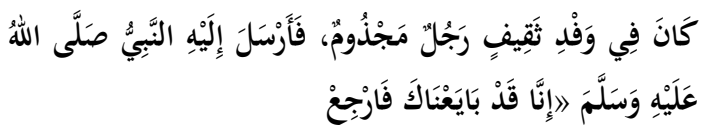

Artinya: bahwa ada salah seorang dari bani Tsaqif yang menderita penyakit kusta ingin memberikan bait langsung kepada Rasulullah, namun Rasulullah tidak 
Vol. 16, No. 2, Desember 2020, p. 122-131

menemuinya, dan mengutus salah seorang sahabat untuk menemui orang tersebut, dan menyampaikan pesan Rasulullah bahwa baitnya telah diterima (Al-Naisaburi, t.t.-b).

Kelima, argumen yang dihembuskan bahwa Covid-19 akan merusak akidah dan tawakal kepada Allah. Terhadap argumen ini, dijawab bahwa ketika seseorang menghindari keburukan, bukan berarti orang tersebut tidak memiliki sifat tawakal, melainkan ingin berpindah dari satu takdir kepada takdir yang lainnya. Hal ini sebagaimana ucapan Umar ibn Khattab ra.,

$$
\text { فَقَالَ نَعَمْ أَفِرْ مَنْ قَدَرِ اللَّهَ إِلَى قَدَرِ اللَّهِ }
$$

Artinya: "Benar, saya lari dari satu takdir Allah, menuju kepada takdir Allah yang lain." (Al-Qurtubi, t.t.).

Adapun persoalan tawakal kepada Allah swt dengan mencari kebaikan adalah bagian daripada menuju kepada ketetapan Allah yang baik, sebagaimana perkataan Umar ibn Khattab ra. dalam kitab al-Muwattha';

$$
\begin{aligned}
& \text { أَرَأَيْتَ لَوْ كَانَ لَكَ إِِِلٌ فَهَبَطَتْ وَادِياً لَهُ عُدْوَتَانِ إِحْدَاهُمَا }
\end{aligned}
$$

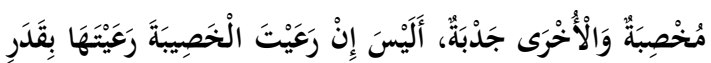

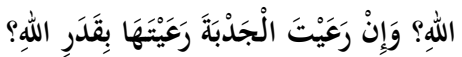

Artinya: "Seandainya engkau memiliki sejumlah unta, kemudian ada dua tempat untuk mengembala, satunya hijau penuh tumbuh-tumbuhan dan yang satunya lagi kering. Jika engkau mengembalakan untamu di tempat yang hijau, menurutmu bukankah itu karena ketentuan Allah? Demikian pula halnya, jika engkau mengembalakannya di tempat yang kering?" (Al-Asbahani, 2004).

Allah swt sendiri telah melarang hambaNya untuk menjerumuskan dirinya ke dalam kebinasaan, sebagaimana firman-Nya dalam Al-Qur'an:

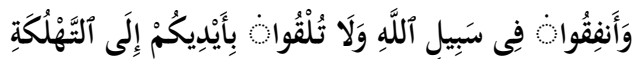

Artinya: "Dan janganlah kamu menjatuhkan diri kamu kedalam kebinasaan." (Q.S AlBaqarah [2]:195)

\section{Kesimpulan}

Berdasarkan hasil penelitian dan pembahasan, dapat disimpulkan bahwa keberadaan wabah sebagai suatu penyakit adalah sesuatu yang nyata, dan bukan merupakan sebuah isu konspirasi. Persepsi, argumentasi dan pemahaman sebagian umat Islam yang menyatakan bahwa wabah Covid19 adalah sebuah konspirasi berpotensi menimbulkan kerusakan dalam tatanan kehidupan bernegara dan bermasyarakat. Selain itu, apabila pemahaman ini tidak diarahkan sesuai tuntunan Islam yang benar, dikhawatirkan akan memberikan dampak buruk terhadap ukhuwah, persaudaraan dan persatuan umat Islam. Adanya sisi kesamaan antara wabah Covid-19 dan wabah yang pernah ada dalam sejarah umat Islam, demikian pula dengan bencana kematian yang ditimbulkannya, bencana materi, bencana sosial, serta jangkauan sebarannya, menjadi dasar kuat untuk dapat menarik benang merah bahwa wabah ini bukanlah sebuah konspirasi. Beberapa anggapan dan argumen yang tidak berdasar terkait wabah ini dapat dijawab, dibantah dan dijelaskan dengan dalil dan bukti yang kuat dan nyata berdasarkan hadis-hadis Rasulullah, riwayatriwayat yang sahih, dan catatan sejarah umat Islam.

\section{Daftar Pustaka}

Al-Asbahani. (2004). Al-Muwattho' (1 ed., Vol. 5). Al-Imarat.

Al-Atsir, I. (1997). Al-Kamil fi al-Tarikh (1 ed., Vol. 2). Beirut: Dar al-Kutub alArabi.

Al-Azadi. (t.t.). Jami' Ma'mar ibn Rosyid (2 ed., Vol. 11). Bakistan: Al-Majlis alIlmi.

Al-Damsiqi. (1997). Al-Bidayah wa alNihayah. Damsiq: Dar Hirun li alTiba'ah wa al-Nasyri' wa al-Tauzi' wa al-I'lan.

Al-Damsiqi, A. Z. (t.t.). Tarikh Abu Zur'ah al-Damsiqi. Damsiq: Mujamma' alLughoh al-Arabiyyah.

Al-Dayanwari. (1992). Al-Ma'arif. AlQohiroh: Al-Haiatu al-Misriyyah alAmah li al-Kutub.

Al-Dzahabi. (1993). Tarikh al-Islam wa Wafayati al-Masyahir wa al-I'lam (2 ed., Vol. 6). Bairut: Dar al-Kutub alArabi. 
Al-Dzahabi. (t.t.). Al-Ibar fi Khabari man Gabar (Vol. 1). Beirut: Dar al-Kutub al-Ilmiyyah.

Al-Dzahabi, I. (2006). Siyar A'lam alNubala' (Vol. 13). Al-Qohiroh: Dar al-Hadis.

Al-Jauzi. (1992). Al-Muntadzom fi Tarikhi al-Umam wa al-Muluk. Beirut: Dar al-Kutub al-Ilmiyyah.

Al-Jundi. (t.t.). Al-Mu'amaratu ala al-Islam (Vol. 1). Dar al-I'tisom.

Al-Mahasin. (t.t.). Al-Nujum al-Zahiroh $f i$ Muluki Miser wa al-Qohiroh (Vol. 1). Mesir: Dar al-Kutub.

Al-Marakisyi, I. A. (1983). Al-Bayan alMugribi fi akhbari al-Andalaus wa al-Magribi (1 ed., Vol. 1). Beirut: Dar al-Tsaqofah.

Al-Nadawi. (t.t.). Al-Sirah al-Nabawiyyah li abi al-Hasan al-Nadawi (12 ed., Vol. 1). Damsiq: Dar Ibnu katsir.

Al-Naisaburi. (t.t.-a). Al-Musnad al-Sahih alMukhtasar bi Naqli al-Adli an alAdli ila Rasulillah Saw (Vol. 3). Beirut: Dar Ihya' al-Turotts al-Arabi.

Al-Naisaburi. (t.t.-b). Sahih Muslim (Vol. 4). Beirut: Dar Ihya' al-Turots al-Arabi.

Al-Qurtubi. (t.t.). Al-Tamhid lima fi alMuwattho' min al_ma'ani wa alAsanid (Vol. 8). Al-Magrib: Wizaratu Umumi al-Auqof wa alSyu'un al-Islamiyyah.

Al-Samiri. (2000). Tarikh al-Arab wa Hadaratihim fi al-Andalus (1 ed., Vol. 1). Beirut: Dar al-Kutub alJadid al-Muttahidah.

Al-Suyuti, J. (2004). Tarikh al-Khulafa'. Maktabatu Nazzar Mustafa al-Baz.

Al-Syafi'i, I. M. (2008). Al-Taudih li Syarhi al-Jami' al-Shohih (1 ed., Vol. 19). Damaskus: Dar al-Falah li al-Bahsi al-Ilmi wa Tahqiq al-Turots.

Al-Tujaibi. (t.t.). Al-Muntaqa Syarhu alMuwattho' (1 ed., Vol. 7). Mesir: Matba'atu al-Sa'adah.

Anggita, K. (2020, Maret 12). Sejarah Pernah Mencatat, 10 Pendemi Terbesar di Dunia. Diambil 29 Desember 2020, dari Medcom.id website: https://www.medcom.id/rona/kesehat an/RkjBQygk-sejarah-pernahmencatat-10-pendemi-terbesar-didunia

Cahyana, B. (2020, Oktober 6). 39,9\% Masyarakat di Provinsi Ini Percaya Covid-19 adalah Konspirasi Global. Diambil 28 Desember 2020, dari Harianjogja.com website: https://news.harianjogja.com/read/20 20/10/06/500/1051814/399masyarakat-di-provinsi-ini-percayacovid-19-adalah-konspirasi-global

Duzi. (2008). Al-Taudih li Syarhi al-Jami' alShohih (1 ed., Vol. 1). Irak: Wizaratu al-Tsaqofah wa al-I'lam.

Dyurant, W. I. (1988). Qissatu al-Hadarah (Vol. 40). Beirut: Dar al-Jil.

Farid, A. (1999). Thoriqu al-Sa'adah (1 ed., Vol. 1). Al-Qohiroh: Maktabatu Ibnu Taimiyyah.

Fauzatul, K. (2020, Mei 16). Cek Fakta: Virus Corona Disebut Senjata dengan 12 Misi Hancurkan Umat Islam Dunia, Ini Faktanya - Pikiran Rakyat Cirebon. Diambil 28 Desember 2020, dari https://cirebon.pikiranrakyat.com/cek-fakta/pr04383750/cek-fakta-virus-coronadisebut-senjata-dengan-12-misihancurkan-umat-islam-dunia-inifaktanya

Fitriani, N. I. (2020). Tinjauan Pustaka Covid-19: Virologi, Patogenesis dan Manifestasi Klinis. Jurnal Medika Malahayati, 4(3). Diambil dari http://ejurnalmalahayati.ac.id/index.p $\mathrm{hp} /$ medika/article/view/3174

Hambal, I. A. (2001). Musnad ail-Imam Ahmad ibn Hambal (1 ed., Vol. 31). Mu'assasatu al-Risalah.

Ibrahim, M. (t.t.). Risalatu al-Fikri fi Zamani al-Udwan.

Jazairi, A. B. J. al; (1994). Aisar al tafasir li kalam al 'aliy al kabir: Juz 1 . Maktabah al Ulum wa al Hikam. 
(Madinah). Diambil dari //10.170.10.3/index.php?p=show_det ail\&id=2608\&keywords $=$

Khayyat. (t.t.). Tarikh Khalifah ibn Khayyat (2 ed., Vol. 1). Beirut: Dar al-Qolam.

Khotib. (t.t.). Al-Rosul al-Qo'id (6 ed., Vol. 1). Beirut: Dar al-Fikr.

Lie, R. (2018, November 30). Seabad Flu Spanyol. Diambil 29 Desember 2020, dari Historia-Majalah Sejarah Populer Pertama di Indonesia website:

https://historia.id/sains/articles/seaba d-flu-spanyol-DBKbm

Mursid, F., \& Firmansyah, T. (2020, Mei 10). Wapres: Kelompok Konservatif Sebut Covid-19 Konspirasi. Diambil 28 Desember 2020, dari Republika Online website: https://republika.co.id/share/qa3zhb3 77

Naufal Dzulfaroh, A. (t.t.). Mengapa Angka Kematian akibat Covid-19 di Asia Lebih Rendah daripada Eropa dan AS? Diambil 29 Desember 2020, dari KOMPAS.com website: https://www.kompas.com/tren/read/2 020/05/31/194500765/mengapaangka-kematian-akibat-covid-19-diasia-lebih-rendah-daripada-eropa

Rahman Nugraha, A. (2020). Indonesia Negara dengan Hoaks dan Teori Konspirasi Corona Terbanyak. Diambil 28 Desember 2020, dari Kumparan website: https://kumparan.com/kumparansains /indonesia-negara-dengan-hoaksdan-teori-konspirasi-coronaterbanyak-1u0JnqOXilm
Ratna Iskana, F. (2020, Oktober 15). Sebanyak 16\% Warga Masih Percaya Teori Konspirasi Terkait Covid-19Nasional Katadata.co.id. Diambil 28 Desember 2020, dari https://katadata.co.id/febrinaiskana/b erita/5f87cab568515/sebanyak-16warga-masih-percaya-teorikonspirasi-terkait-covid-19

Supriatna, E. (2020). Wabah Corona Virus Disease Covid 19 Dalam Pandangan Islam. SALAM: Jurnal Sosial dan Budaya Syar-i, 7(6), 555-564. https://doi.org/10.15408/sjsbs.v7i6.1 5247

Syandri. (2020). Qadariyah, Jabariyah dan Ahlussunnah (Studi Komparatif Merespon Kebijakan Pemerintah dan Fatwa MUI Dalam Mencegah Penularan Covid-19). 1, 209-222. https://doi.org/10.1234/bustanul.v1i2 .147

Usman, M. H., Aswar, A., \& Sam, Z. (2020). Covid-19 dalam Perjalanan Akhir Zaman: Sebab, Dampak dan Anjuran Syariat dalam Menghadapinya. BUSTANUL FUQAHA: Jurnal Bidang Hukum Islam, 1(2), 137-155. https://doi.org/10.36701/bustanul.v1i 2.142 